\title{
REFORMASI SOSIAL DALAM SITTI NURBAYA DAN RELEVANSINYA SEBAGAI MATERI AJAR SASTRA INDONESIA DI SMA
}

\author{
Achmad Yuhdi \\ Program Studi Pendidikan Bahasa dan Sastra Indonesia \\ Universitas Negeri Medan \\ Jalan Willem Iskandar Pasar V Medan Estate, Medan \\ Surel: yuhdiachmad@unimed.ac.id
}

\begin{abstract}
Abstrak
Pembicaraan tentang roman Siti Nurbaya karya Marah Rusli yang diterbitkan perdana pada tahun 1920 oleh Balai Pustaka, dipandang banyak orang sudah tidak relevan lagi pada masa sekarang. Anggapan tersebut dimungkinkan karena selama ini apresiasi terhadap roman tersebut masih sekadar kisah percintaan antara tokoh Nurbaya dengan Syamsul Bahri yang tidak terwujud karena kerakusan Datuk Maringgi. Tulisan sederhana ini bertujuan untuk menepis tanggapan tersebut. Pada akhir bagian pembahasan ini diharapkan pembaca dapat menarik simpulan bahwa membaca Roman Siti Nurbaya masih relevan dibaca hingga saat ini. Secara khusus tujuan penelitian ini untuk mendeskripsikan reformasi sosial yang terdapat di dalam novel dan mengkaji kelayakannya sebagai materi ajar sastra di SMA. Penelitian sederhana ini menggunakan metode deskriptif. Pemaknaan terhadap teks sastra dalam roman ini menggunakan pendekatan sosiologi sastra. Hasil pengkajian terhadap roman ini menunjukkan bahwa selain tema tentang perkawinan paksa, Marah Rusli juga menyampaikan kritik terhadap berbagai masalah sosial lainnya yang terjadi pada masayrakat Minangkabau pada masa itu. Upaya untuk mereformasi beberapa pandangan masyarakat Minangkabau diupayakan dalam novel ini melalui beberapa tokoh seperti Sultan Mahmud dan Syamsul Bahri. Terkait hal itu, hasil analisis terhadap Sitti Nurbaya dipandang dari tinjauan sosiologi sastra relevan disajikan sebagai materi ajar sastra Indonesia di SMA. Hal ini dipandang dari beberapa alasan, yang diantaranya: memuat banyak nilai moral yang dapat diteladani generasi milenial saat ini dalam pergaulan sehari-hasi kepada rekan sebaya dan orang yang lebih tua.
\end{abstract}

Kata kunci: Reformasi Sosial, Masyarakat Minang, Siti Nurbaya.

\section{A. PENDAHULUAN}

Sebagaimana diketahui bersama, roman Siti Nurbaya: Kasih Tak Sampai karya Marah Rusli merupakan karya sastra unggulan pada tahun 1920-an atau yang sering dikenal dengan angkatan balai pustaka. Pembahasan tentangnya hingga kini dipandang selalu relevan dan tak hentinya digali oleh akademisi/budayawan. Anggapan ini disampaikan Setiawan (2019). Menyimpulkan bahwa novel Sitti Nurbaya sangat lengendaris dan tidak lekang oleh waktu, karena pembahasan di dalamnya menceritakan tentang adat istiadat, perilaku ikon adat, dan kebiasaan dari adat Minangkabau. Selain itu, berbagai publikasi ilmiah tentang Sitti Nurbaya pada rentang waktu sepuluh tahun terakhir juga masih dilakukan. Beberapa diantaranya Senja, P (2017) yang membahas roman ini dari sudut pandang kajian intertekstual. Karya Marah Rusli ini dihadapkannya dengan novel Laila Majnun karya Syaikh Nizami. Baroroh, N (2015) membahas roman 
ini sebagai bahan ajar dalam mengidentifikasi kebiasaan, adat, dan etika yang terdapat dalam roman ini, yang diajarkan kepada siswa melalui pendekatan STAD. Supriatin, Y.M (2010) menggali nilai-nilai nasionalisme yang diperjuangkan Marah Rusli melalui para tokoh yang tergambar dalam roman tersebut.

Melalui Sitti Nurbaya, Marah Rusli dapat menghidupkan suasana novel sehingga menjadi kisah yang melegenda bagi masyarakat Indonesia. Hingga saat ini, zaman Sitti Nurbaya dikenal sebagai zaman perjodohan, itulah yang telah melekat. Selain Sitti Nurbaya, Marah Rusli juga mengkritik perihal perjodohan ini melalui novelnya yang lain berjudul Memang Jodoh. Novel ini bercerita tentang pengalamannya sendiri dalam menemui cinta sejatinya. Dengan polemik yang tak kunjung usai dari kaum adatnya di Padang. Kaum adatnya di Padang memaksa dia untuk menikah lagi dengan perempuan asli Minangkabau (Atria, dkk: 2019).

Apresiasi terhadap roman Sitti Nurbaya juga tak luput disampaikan kritikus sekaligus akademisi sastra terkemuka di negeri ini. Roman Siti Nurbaya menjadi salah satu objek kajiannya dalam penyelesaian disertasi doktor di bidang sastra, yakni oleh Faruk (2002) yang mengulas Siti Nurbaya ditinjau dari kategorisasi ciri novel Balai Pustaka lainnya yang bercorak romantisisme. Juga, Trisnawati (2019) yang menggali kandungan nilai sosial, seperti toleransi, tolong-menolong, ramah dan sopan santun, membantu sesama, kasih sayang dan tolong-menolong, dan menepati janji. Keberhasilan Sitti Nurbaya menarik perhatian pembaca tentu tak lepas dari tangan dingin penulis Marah Rusli. Ia merupakan pengarang yang dapat mencipatakan karya sastra yang paling banyak dibaca oleh masyarakat. Ia berhasil menciptakan mimikri sebagai satu bentuk resistensi yang dilakukan terhadap kolonial Belanda. (Artawan: 2015).

Berdasarkan beberapa kajian yang disebutkan di atas, tak satupun artikel yang membahas tentang upaya penulis (Marah Rusli) melakukan reformasi terhadap tatanan sosial masyarakat Minangkabau pada masa itu. Juga dalam hal pengayaan terhadap materi ajar sastra Indonesia di tingkat SMA/sederajat. Karena itulah, tulisan ini memiliki nilai kebaharuan dari artikel lain yang sudah dipublikasikan sebelumnya terkait pengkajian roman Sitti Nurbaya ini.

Penggalian isi cerita Sitti Nurbaya pada masa sekarang ini seharusnya tidak lagi fokus pada kisah asmara tokoh Nurbaya dengan Syamsul Bahri yang tidak terwujud karena kehadiran tokoh Datuk Maringgi yang memaksakan kehendaknya untuk 
mengawini Nurbaya. Penggambaran kisah kasih dua tokoh utama itu, sesungguhnya digunakan si penulis hanya untuk menyamarkan pesan yang ingin disampaikan kepada pembaca, karena pada masa itu sangat ketat sensor yang dilakukan oleh Balai Pustaka. Oleh karenanya, pengkajian terhadap Sitti Nurbaya pada penelitian ini, difokuskan pada penggalian pesan-pesan ideologi si penulis, khususnya terkait masalah sosial masyarakat pada masa itu. Tulisan ini juga, pada akhirnya akan direkomendasikan bagi guru bahasa dan sastra Indonesia tingkat SMA/sederajat sebagai memperkaya khasanah materi ajar sastra Indonesia pada KD 2.6 Menginterpetasi makna teks cerita sejarah, berita, iklan, editorial, dan novel yang baik secara lisan maupun tulisan.

Alasan dipilihnya roman Sitti Nurbaya dalam penelitian sederhana ini, karena roman ini merupakan dokumentasi karya sastra yang sarat akan nilai sejarah perkembangan kesusasteraan modern di Indonesia. Roman ini--meskipun bukan termasuk novel Indonesia modern pertama yang terbit pada angkatan Balai Pustaka, tetapi dipandang sebagai pioneer/unggulan dari karya sastra pada masa itu. Sarwadi (dalam Hartono: 2005) mengatakan bahwa Sitti Nurbaya merupakan sebagai puncak kejayaan Balai Pustaka. Oleh karenanya, mahasiswa calon guru bahasa Indonesia, guru bahasa Indonesia harus mengetahui secara kompleks isi cerita dan pesan yang ingin disampaikan oleh penulis novel tersebut. Harapannya, melalui tulisan ini, guru bahasa Indonesia tidak lagi hanya mengajarkan novel Sitti Nurbaya hanya dari sisi cerita kawin paksa saja, tetapi lebih dari itu, yakni permasalahan sosial, nilai budaya, nilai pendidikan, nilai nasionalisme yang merupakan pesan penting yang ingin disampaikan penulis kepada pembaca.

Berbagai upaya reformasi tatanan kehidupan sosial masyarakat Minangkabau dilakukan dalam Sitti Nurbaya melalui dialog tokoh Sultan Mahmud dengan kakanya yang bernama Rubiah. Sultan Mahmud mewakili tokoh pembaharu, sementara Rubiah mewakili masyarakat Minangkabau pada umumnya di masa itu. Terkait kegiatan apresiasi yang dilakukan dalam penelitian ini, Yuhdi (2020) menegaskan bahwa pemaknaan terhadap karya sastra perlu dilakukan komprehensif. Adapun tujuan kajian ini, yaitu (i) untuk mengetahui bagaimana upaya melakukan perubahan sosial di masyarakat Minagkabau dalam pendekatan sosiologi sastra, dan (ii) menjelaskan implikasi implementasi kajian terhadap novel Sitti Nurbaya untuk pengayaan materi ajar sastra Indonesia di SMA. 


\section{B. KAJIAN TEORI}

\section{Reformasi Sosial}

Pengkajian reformasi sosial masyarakat dalam sebuah novel juga dilakukan oleh Fawziah (2017) yang membahas tentang perubahan sosial masyarakat Jawa dalam novel Suti karya Sapardi Djoko Damono. Hasil penelitiannya menjelaskan bahwa proses perubahan sosial pada masyarakat Jawa yang terdapat pada novel Suti ini terjadi secara evolutif dan damai.

Pembicaraan tentang reformasi sosial dalam karya sastra, tentu tidak terlepas dari pengkajian sosiologi sastra sebagai teori yang memayungi masalah tersebut. Pendekatan sosiologi sastra memandang bahwa karya sastra yang diciptakan pengarang merupakan tiruan/ mimesis dari kondisi realita masyarakat. Damono (1978) menegaskan bahwa karya sastra tidak jatuh begitu saja dari langit, melainkan memiliki sangkutan antara pengarang, karya, dan masyarakat. Oleh sebab itu, memahami karya sastra tidak dapat dilepaskan dari ketiga aspek yang dimaksud, yakni: pengarang sebagai anggota masyarakat, kondisi sosial budaya, politik, ekonomi yang ikut berperan dalam kehadiran karya sastra itu, serta pembaca yang akan menikmatinya.

Selanjutnya, Ian Watt (dalam Winarni, R, 2009:167) menjelaskan praktik kajian sastra, bila melihat karya sastra sebagai cermin masyarakat, maka pengkajiannya meliputi: (1) sejauh mana sastra mencerminkan masyarakat pada waktu karya sastra ditulis, (2) sejauh mana sifat pribadi pengarang mempengaruhi gambaran masyarakat yang ingin disampaikannya, (3) sejauh mana genre sastra yang digunakan pengarang dapat mewakili seluruh masyarakat. Sementara itu, Endraswara (2013, hlm. 166) menjelaskan focus pengkajian sosiologi sastra terdapat banyak di dalam novel. Hal itu karena beberapa alasan, yakni: (a) mendeskripsikan perubahan tokoh dalam kehidupan sosial, (b) mendeskripsikan manusia dalam kehidupan di masyarakat, (c) merupakan karya yang cukup memadai dikaji sebagai penelitian, dan (d) memiliki keutuhan hidup sosial yang mencerminkan masyarakat di luar karya sastra itu.

Istilah reformasi dalam KBBI berarti perubahan terhadap suatu sistem yang telah ada pada suatu masa. Oleh karenanya, reformasi sosial dapat juga diartikan sebagai perubahan sosial. Perubahan sosial merupakan perubahan-perubahan yang terjadi pada lembaga-lembaga kemasyarakatan dalam suatu masyarakat yang memengaruhi sistem sosialnya, termasuk nilai, sikap-sikap sosial, dan pola perilaku di antara kelompok- 
kelompok dalam masyarakat. Kingsley Davis (dalam Soerjono: 1990) mengungkapkan bahwa perubahan sosial sebagai perubahan-perubahan yang terjadi dalam struktur dan fungsi masyarakat. Oleh karenanya, definisi operasional terhadap reformasi sosial yang dimaksud dalam penelitian ini adalah upaya penulis dalam melakukan perubahan dimensi kehidupan sosial masyarakat terhadap sebagian besar adat-istiadat Minangkabau yang dianggap salah ditafsirkan dalam kehidupan sehari-hari pada masa itu.

\section{Pengembangan Materi Ajar}

Bahan ajar adalah seperangkat sarana atau alat pembelajaran yang berisikan materi pembelajaran, metode, batasan-batasan, dan cara mengevaluasi yang didesain secara sistematis dan menarik dalam rangka mencapai tujuan yang diharapkan, yaitu mencapai kompetensi atau subkompetensi dengan segala kompleksitasnya, sedangkan menurut Lestari (2013:1) bahan ajar haruslah dirancang dan ditulis dengan kaidah intruksional karena akan digunakan oleh dosen untuk membantu dan menunjang proses pembelajaran. Bahan atau materi pembelajaran pada dasarnya adalah "isi" dari kurikulum, yakni berupa mata pelajaran atau bidang studi dengan topik/subtopik dan rinciannya (Ruhimat 2011:152).

Bahan ajar disusun dengan melihat berbagai macam tujuan yang ingin dicapai dalam kurikulum yang sedang digunakan yang selanjutnya terealisasikan melalui pembelajaran di dalam kelas. Menurut Majid (2005:15), bahan ajar disusun dengan memiliki beberapa tujuan. Adapun tujuan-tujuan tersebut adalah sebagai berikut: 1.) Membantu siswa dalam mempelajari sesuatu. 2.) Menyediakan berbagai jenis pilihan bahan ajar. 3.) Memudahkan guru dalam melaksanakan pembelajaran. 4.) Agar kegiatan pembelajaran menjadi menarik.

Pada pelaksanaan kurikulum 2013 sebagian besar materi atau buku ajar sudah disiapkan oleh pemerintah pusat, meskipun materi atau bahan ajar sudah tersedia bukan berarti guru tidak perlu mengembangkan bahan sendiri sebagai bahan ajar pengayaan. Bagi siswa, seringkali bahan yang terlalu banyak membuat mereka bingung, untuk itu maka guru perlu membuat bahan ajar pengayaan untuk menjadi pedoman bagi siswa.

Zukhaira (2014) menegaskan ada sejumlah manfaat yang dapat diperoleh apabila seorang guru atau dosen mengembangkan bahan ajar sendiri, yakni antara lain; pertama, diperoleh bahan ajar yang sesuai dengan kebutuhan belajar siswa atau mahasiswa, kedua, tidak lagi tergantung kepada buku teks yang terkadang sulit untuk diperoleh, ketiga, 
bahan ajar menjadi labih kaya karena dikembangkan dengan menggunakan berbagai referensi, keempat, menambah khasanah pengetahuan dan pengalaman guru atau dosen dalam menulis bahan ajar, kelima, bahan ajar akan mampu membangun komunikasi pembelajaran yang efektif antara guru dengan siswa karena siswa akan merasa lebih percaya kepada gurunya.

\section{METODE PENELITIAN}

Penelitian ini merupakan studi sosiologi sastra yang fokus pada teks karya sastra sebagai dasar untuk melihat gejala sosial di luar teks. Teknik pengumpulan data yang diterapkan dalam penelitian adalah teknik baca simak dan teknik catat. Teknik baca simak, yaitu pembacaan yang saksama terhadap kedua novel yang menjadi objek kajian. Teknik catat adalah pencatatan terhadap data-data di dalam novel yang disesuaikan dengan keperluan penelitian, yaitu yang berkaitan dengan reformasi sosial dalam Sitti Nurbaya. Metode analisis data menggunakan metode deksriptif analisis dengan teknik interpretatif. Pendekatan pengkajian yang digunakan adalah sosiologi sastra. Data yang diperoleh kemudian dianalisis secara sosiologi sastra. Sifat penelitian ini adalah deskriptif yang memaparkan data dan hasil penelitian dalam bentuk kata-kata.

\section{HASIL PENELITIAN DAN PEMBAHASAN}

Upaya Marah Rusli untuk mengkritisi budaya adat istiadat Minangkabau terlihat mulai bagian kedua novel ini yang diberi judul 'Sutan Mahmud dengan Saudaranya yang Perempuan'. Selain itu, upaya reformasi tatanan kehidupan sosial juga ditunjukkan dengan dikesampingkannya peran ninik mamak yang seharusnya begitu penting fungsinya dalam keluarga Minangkabau. Fauzi (2016) menyatakan persoalan peran dan fungsi ninik mamak yang tidak ditonjolkan dalam Sitii Nurbaya, dapatlah dipandang dengan sangat janggal mengingat pentingnya posisi ninik mamak dalam sistem kekerabatan di Minangkabau. Juga diketahui bersama, terdapat uangkapan di tengah masyarakat Minangkabau berbunyi anak dipangku kamanakan dibimbiang. Dalam hal ini mamak berkewajiban membimbing kemenakan dalam bidang adat, bidang agama, dan perilaku sehari-hari.

\section{Reformasi Sosial Sitti Nurbaya karya Maral Rusli}

Berdasarkan pandangan di atas, hasil penelitian terkait reformasi sosial Sitti Nurbaya terdiri dari: a) kedudukan laki-laki berpangkat di masyarakat Minangkabau, b) 
kedudukan seorang ayah tentang tanggung jawab kepada anak, dan c) kedudukan perempuan di masyarakat.

\section{a) Kedudukan Laki-laki Berpangkat di Masyarakat Minangkabau}

Suatu hal yang wajar bagi lelaki bangsawan di Minangkabau menikahi lebih dari satu orang gadis. Bahkan, akan menjadi aneh bagi masyarakat masa itu, bila melakukan hal sebaliknya. Perangai demikian ditunjukkan oleh Sutan Hamzah, yakni adik kandung dari Sutan Mahmud yang notabene berasal dari keturunan bangsawan. Ungkapan ini ditunjukkan melalui pernyataan tokoh Putri Rubiah dan Sutan Hamzah ketika membicarakan Sutan Mahmud sebagaimana pada kutipan berikut.

"memang engkaulah saudaraku yang sesungguh-sungguhnya, membangkitkan batang terendam, yang tahu adat istiadat dan menjunjung tinggi pusaka nenek moyang dan tahu menghargakan ketinggian kebangsawanan kita. (Rusli: 58).

Apabila mentua hamba tiada cakap atau tiada sudi lagi memelanjai hamba, hamba ceraikan anaknya dan hamba kawini perempuan lain, yang mampu; tentu dapat hamba uang jemputan dua tiga ratus rupiah dan berisilah pula kocek hamba. (Rusli: 58)

Kritik sosial penulis terhadap kondisi masyarakat Minangkabau sebagaimana disebutkan di atas, ditunjukkan melalui sikap tokoh Sutan Mahmud yang menentang adat istiadat tersebut dengan hanya menikahi satu perempuan saja sebagai seorang istri dan ditambah lagi istri yang dipilihnya bukan berasal dari keturunan bangsawan.

Sekalian Penghulu di Padang ini beristri dua, tiga, sampai empat orang. Hanya engkau sendirilah yang dari dahulu, hanya perempuan itu saja istrimu tidak berganti-ganti, tiada bertambah-tambah.

"Sampai sekarang aku belum mengeri, bagaimana pikiranmu, tatkala mengawini perempuan itu. Apanya yang kaupandang? Bagusnya itu saja? Apa gunanya beristri bagus, kalau bangsa taka da, Serdadu Belanda bagus juga, tetapi siapa yang suka menjemputnya? (Rusli: 22)

Selain dua kutipan roman yang disebutkan di atas, bentuk kritik sosial penulis juga disampaikan melalai berbagai kisah sedih kehidupan keluarga, terutama nasib perempuan yang dimadu oleh laki-laki yang berlindung dalih adat istiadat dan ajaran agama. Terkait dengan perlindungan dari pandangan ajaran agama, penulis membantah melalui pernyataan "Walaupun tersebut dalam kitab (agama), laki-laki boleh beristri sampai empat orang, tapi haruslah harta si laki-laki itu berlebih dahulu daripada untuk memelihara seorang istri dengan sempurna dan haruslah pula ia adil dengan seadil-adilnya, dalam segala hal. (Rusli: 198) 


\section{b) Kedudukan Seorang Ayah tentang Tanggung Jawab kepada Anak}

Tanggung jawab seorang ayah terhadap pendidikan anaknya sudah seharusnya diberikan secara maksimal. Ada ungkapan biar kaki jadi kepala, kepada jadi kaki, asalkan sampai cita-cita anakku. Namun, ungkapan ini tak sepenuhnya berterima dalam adat masyarakat Minangkabau yang digambarkan dalam Sitti Nurbaya. Seorang anak tidak sepenuhnya tanggung jawab ayah. Dalam Sitti Nurbaya, bahkan lebih ekstrim lagi dikatakan bahwa tidak mengindahkan adat istiadat bila seorang ayah terlalu memperhatikan kehidupan anaknya. Dalam roman ini, beberapa pemikiran tokoh mewakili pemikiran masyarakat pada saat itu, yakni tokoh Putri Rubiah dan Sutan Hamzah.

"Lihatlah! Memang benar sangkaku, pikiranmu telah berubah daripada yang diadatkan di Padang ini. Istrimu sudahlah, sebab ia tinggal di rumahmu, tetapi anakmu? Bukanlah ada mamandanya, saudara istrimu? Bukankah anakmu itu kemanakannya? Bukankah dia yang harus memelihara anakmu, menurut adat kita?” Atau telah lupa engkau adat nenek moyang kita itu? (Rusli: 21)

Upaya merubah pandangan fanatik terhadap adat istiadat masyarakat Minangkabau diwujudkan penulis melalui sikap tokoh Sutan Mahmud yang tidak terlalu mengindahkan kebiasaan masyarakat masa itu dengan menyerahkan sepenuhnya perihal kehidupan anak kepada seorang mamanda (sebutan untuk saudara laki-laki dari pihak ibu). Tokoh Sutan Mahmud lebih memilih mendidik putranya Samsulbahri dengan pola asuh tangannya sendiri. Dalam roman ini, Samsulbahri dikisahkan dengan penuh perhatian orang tua disekolahkan hingga ke Pulau Jawa. Hal ini merupakan sesuatu yang tidak lumrah terjadi pada masa itu. Kritik penulis terhadap hal ini dilihat dari kalimat, "Lagi pula hamba sekolahkan si Samsu bukan karena apa-apa, melainkan sebab pada pikiran hamba, kewajiban bapaklah memajukan anaknya” (Rusli:. 22).

Kritik lain yang ingin disampaikan terkait adat istiadat dan tatanan masyarakat Minangkabau pada saat itu ialah terkait penilaian tentang sebuah kesuksesan. Menurut mereka, bahagia atau celakanya, kehidupan seseorang hanya bergantung kepada nasib yang sudah ditetapkan. Hal ini diungkapkan Sutan Hamzah kepada saudara perempuannya Putri Rubiah ketika membicarakan perangai Sutan Mahmud sebagaimana kutipan berikut.

... Bukankah sekaliannya itu bergantung kepada untung nasib satu-satunya orang? Jika baik untungnya, tak pandai pun, tentu akan mendapat pangkat 
juga. Tetapi apabila tak baik nasib, walaupun melangit kepandaiannya, jatuhnya ke pelimbahan juga. (hlm. 57).

... Apakah sebabnya ditanggung yang tak perlu ditanggung dan disuruh pula menuntut ilmu kemana-mana. Itulah yang dikatakan orang tak beban, batu di gelas. Siapa yang mau berbuat sedemikian, waktu ini? Hanya ia sendiri. Pada sangkanya, akan dipuji orang perbuatannya ini. Tidak diketahuinya, bahwa ia dicerca dan ditertawakan orang dari belakang. (Rusli: 58)

Dalam KBBI kata pelimbahan diartikan sebagai tempat rendah atau lubang yang sengaja digali untuk tempat membuang air kotor dan sebagainya. Selain ungkapan dua tokoh di atas, adat istiadat tentang peran seorang mamanda dalam keluarga Minangkabau juga disampaikan melalui tokoh Ahmad Maulana yang dapat dilihat pada kutipan berikut.

Ayahnya bukankah masih ada? Masakan tiada dipedulikannya anakanaknya? Jawab Fatimah, istrinya. Ayahnya? Tanya Ahmad Maulana, sambil memandang istrinya dengan merengut. "Uh, masakan mau ia menanggung beban itu! Bukankah telah menjadi adat di sini, anak pulang kepada mamak. (Rusli: 191).

Dalam salah satu kisah yang terdapat di roman Sitti Nurbaya, diceritakan bahwa Sutan Hamzah memiliki sepuluh orang istri dan delapan belas anak. Pada masa itu, keadaan demikian wajar dilakukan oleh seorang bangsawan. Pada bagian lain dari roman ini, dikisahkan salah seorang istri Sutan Hamzah meninggal dunia, bernama Rapiah yang meninggalkan dua orang anak. Kejadian ini merupakan bagian kecil dari banyaknya kerusakan yang terjadi di masyarakat sebagai akibat dari adat istiadat yang salah itu.

\section{c) Kedudukan Perempuan di Masyarakat Minangkabau}

Perlakuan adat istiadat Minangkabau terhadap perempuan dipandang tidak adil oleh Marah Rusli. Hal ini dapat disimpulkan melalui berbagai pernyataan yang terdapat dalam roman Sitti Nurbaya. Pertama: perempuan tidak terlalu penting untuk mendapatkan pendidikan yang tinggi. Pemikiran ini ditunjukkan melalui pernyataan berikut, "Sudah berapa kali hamba minta kepada Kakanda, supaya anak itu disekolahkan, tetapi Kakandalah yang tak suka, karena tak baik, kata Kakanda, anak perempuan pandai menulis dan membaca; suka menjadi jahat. (Rusli: 23). Kedua, perempuan sebaiknya lebih cepat menikah, sebagaimana pernyataan, Wahai, kasihan Anakku! Celaka benar untungnya. jodohnya pun tak dapat pula dicarikannya. Anak orang umur 12 atau 13, setua-tuanya umur 14 tahun, telah dikawinkan (Rusli: 22).

Keadaan perempuan dalam Sitti Nurbaya memanglah sangat memperihatinkan. Kehidupan mereka, ketika sudah remaja hingga dewasa hanya kepada tiga tempat saja, 
yakni kasur, dapur, dan sumur. Kondisi yang demikian itu disampaikan dalam pernyataan berikut, "Apabila telah berumur tujuh-delapan tahun mulailah dikurung sebagai burung, tiada diberi melihat langit dan bumi, sehiingga tiadalah tahu apa yang terjadi sekeliling kita. Sedangkan pakaian dan makanan, tiada diindahkan, apalagi kehendak dan kesukaan hati. Sementara itu, kita disuruh belajar memasak, menjahit, menjaga rumah tangga, sekalinya pekerjaan tiada menambah kekuatan dan menajamkan pikiran. (Rusli: 204)

Mengakhiri pengkajian ini, peneliti mengutip pernyataan Marah Rusli melalui tokoh Ahmad Maulana, yang hemat peneliti merupakan simpulan dari berbagai kritik sosial terdapat adat istiadat Minangkabau yang disampaikan dalam roman Sitti Nurbaya. Uangkapan itu adalah, "Sebenarnya pikiranku, sekali-kali tiada setuju dengan adat beristri banyak; karena terlebih banyak kejahatannya daripada kebaikannya, "kata Ahmad Maulana, sambil termenung menghembuskan asap rokoknya. "banyak kecelakaannya yang sudah kudengar dan banyak sengsaranya, yang sudah kulihat dengan mata kepalaku sendiri. (Rusli: 193).

Berdasarkan analisis terhadap reformasi sosial yang dimaksud penelitian ini, bagian selanjutnya digambarkan kategorisasi terhadap tokoh-tokoh dalam Sitti Nurbaya ditinjau dari perwakilan masyarakat memegang teguh adat istiadat/konvensional dan tokoh reformasi/pembaharu.

Tabel 1 Kategorisasi Tokoh Konvensional dan Pembaharu dalam Sitti Nurbaya

\begin{tabular}{c|c|c}
\hline \multirow{2}{*}{ Nama Tokoh } & \multicolumn{2}{|c}{ Kategorisasi Masyarakat } \\
\cline { 2 - 3 } Konvensional & Pembaharu \\
\hline Sitti Nurbaya & \multicolumn{2}{|c}{$\sqrt{ }$} \\
\hline Samsulbahri & $\sqrt{ }$ & \\
\hline Datuk Meringgih & $\sqrt{ }$ & \\
\hline Sutan Mahmud Syah & $\sqrt{ }$ & \\
\hline Baginda Sulaiman & $\sqrt{ }$ & \\
\hline Rukiah & $\sqrt{ }$ & \\
\hline Putri Rubiah & $\sqrt{ }$ & \\
\hline Sutan Hamzah & $\sqrt{ }$ & \\
\hline Pak Ali & $\sqrt{ }$ & \\
\hline Zainularifin & $\sqrt{ }$ & $\sqrt{ }$ \\
\hline Bahtiar & $\sqrt{ }$ & \\
\hline Sitti Maryam & & \\
\hline Sitti Alimah & $\sqrt{ }$ & \\
\hline Tuan Schout & & \\
\hline Ahmad Maulana & & \\
\hline Fatimah & &
\end{tabular}


Berdasarkan uraian data kategorisasi tokoh konvensional dan pembaharu dalam Sitti Nurbaya sebagaimana yang diungkapkan tabel di atas, diketahui bahwa persentasi tokoh-tokoh yang menggambarkan upaya reformasi sosial masyarakat bernilai sekitar $37,5 \%$ lebih kecil/sedikit dibandingkan tokoh-tokoh yang masih mempertahankan adat istiadat Minangkabau senilai 62,5\% dalam novel Sitti Nurbaya tersebut. Perbandingan persentasi itu dapat dilihat pada gambar berikut.

\section{Gambar 1 Perbandingan Persentasi Tokoh-Tokoh Perwakilan Masyarakat Konvensional dan Masyarakat Pembaharu dalam Sitti Nurbaya}

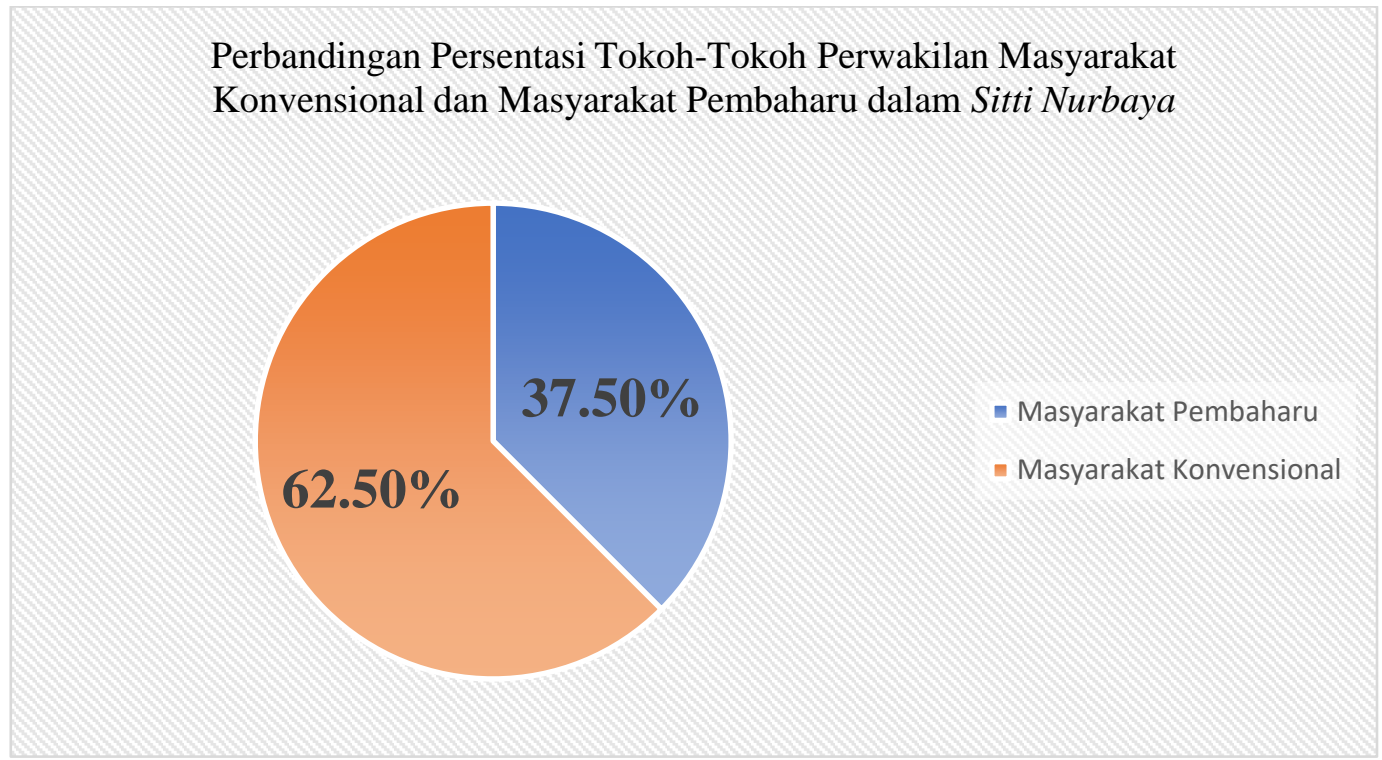

\section{Relevansi Sitti Nurbaya sebagai Materi Ajar Sastra Indonesia}

Roman Sitti Nurbaya karya Marah Rusli mempunyai keterkaitan dalam pembelajaran bahasa Indonesia di sekolah dalam pembelajaran menganalisis novel di kelas XII SMA. Terdapat kompetensi dasar tentang pembelajaran sastra dalam kurikulum 2013, semakin membuat roman ini layak digunakan sebagai materi ajar sastra di SMA. Selain itu, melihat kedudukan roman ini dalam perkembangan sejarah kesusastraan Indonesia modern juga semakin menguatkan pentingnya roman ini untuk diapresiasi di tingkat SMA dan digunakan sebagai materi ajar sastra Indonesia. Kesesuaian roman ini sebagai materi ajar sesuai dengan Kompetensi Dasar (KD) Menganalisis struktur dan kaidah teks cerita sejarah, berita, iklan, editorial/opini, dan novel baik melalui lisan maupun tulisan. Oleh karena itu, roman Sitti Nurbaya karya Marah Rusli relevan untuk dijadikan sebagai materi ajar pada kelas XII SMA. 


\section{E. SIMPULAN}

Berdasarkan ulasan pada hasil penelitian dan pembahasan yang terdapat pada bagian sebelumnya, disimpulkan bahwa upaya mereformasi tatanan kehidupan sosial dalam roman Sitti Nurbaya karya Marah Rusi dapat dilihat dalam tiga hal, yakni: 1) Kedudukan laki-laki berpangkat di masyarakat Minangkabau, 2) kedudukan seorang ayah tentang tanggung jawab kepada anak, dan 3) kedudukan perempuan di tengah masyarakat. Adapun hasil pengkajian roman Sitti Nurbaya dari sundut pandang sosiologi sastra ini dapat digunakan sebagai bahan pengayaan oleh guru ketika mengajarkan sastra Indonesia di kelas X SMA, terutama pada KD 2.6 Menginterpetasi makna teks cerita sejarah, berita, iklan, editorial, dan novel yang baik secara lisan maupun tulisan.

\section{F. SARAN}

Berdasarkan hasil penelitian terhadap novel Sitti Nurbaya karya Marah Rusli di atas, penulis memberikan saran kepada pembaca/penikmat sastra agar setelah membaca karya sastra, juga membaca analisis yang sudah dipublikasikan dalam berbagai jurnal ilmiah terhadap karya sastra tersebut. Hal ini berguna untuk memaknai karya sastra secara komprehensif. Kepada peneliti selanjutnya, disarankan untuk terus menggali makna yang tersirat dalam karya sastra yang ditulis oleh sastrawan Indonesia.

\section{G. DAFTAR PUSTAKA}

Artawan, I Gde. (2015). Mimikri Dan Stereotipe Kolonial Terhadap Budak dalam NovelNovel Balai Pustaka. Jurnal Ilmu Sosial dan Humaniora 4 (1), 557-584. DOI: http://dx.doi.org/10.23887/jish-undiksha.v4i1.4926

Asteka, P. (2017). Kajian Intertekstualitas dalam Novel Siti Nurbaya Karya Marah Rusli dan Laila Majnun Karya Syaikh Nizami. BAHTERA INDONESIA: Jurnal Penelitian Pendidikan Bahasa dan Sastra Indonesia. 2 (2), 13-21. DOI: https://doi.org/10.31943/bi.v2i2

Atria, dkk. (2019) Adat Pernikahan Di Minangkabau Tahun 1900-an dalam Dua Karya Marah Rusli (Sebuah Studi Historigrafi). GALANGGANG SEJARAH 1 (3) 394-407. DOI:10.5281/zenodo.3515207

Baroroh, N. (2015). Pembelajaran Mengidentifikasi Kebiasaan, Adat, dan Etika pada Novel Siti Nurbaya Melalui Model STAD. DIDAKTIKUM: JURNAL PENELITIAN TINDAKAN KELAS. 16 (4) 17-23.

Endraswara. S. (2013). Sosiologi Sastra: Studi, Teori, dan Interpretasi. Yogyakarta: Penerbit Ombak.

Faruk. (2002). Novel-Novel Indonesia: Tradisi Balai Pustaka 1920-1942. Yogyakarta: Gama Media. 
Fauzi, R. A, Sahrul, dan Nuri, N. (2016). Bayang di Balik Tiang: Reinterpretasi Atas Novel Sitii Nurbaya Karya Marah Roesli. BERCADIK: JURNAL PENGKAJIAN DAN PENCIPTAAN SENI, 3 (2) 135-144. https://journal.isipadangpanjang.ac.id/index.php/Bercadik/article/view/546/363

Fawziah (2017). Perubahan Sosial Masyarakat Jawa dalam Novel Suti. Andragogi Jurnal Diklat Teknis. V (1), 1-19.

Hartono. (2005). Mimikri Pribumi Terhadap Kolonialisme Belanda Dalam Novel Sitti Nurbaya Karya Marah Rusli (Kajian Postkolonialisme): JURNAL DIKSI. 12 (2), 75-85. DOI: https://doi.org/10.21831/diksi.v12i2.5267

Lestari. (2013). Pengembangan Bahan Ajar Berbasis Kompetensi. Padang: Akademia Permata.

Majid, Abdul. (2005). Perencanaan Pembelajaran Mengembangkan Standar Kompetensi Guru. Bandung: Rosdakarya.

Ruhimat, Toto. Dkk, (2011). Kurikulum dan Pembelajaran. Jakarta. PT Raja Grafindo Persada.

Rusli, M. (2002). Sitti Nurbaya Kasih Tak Sampai. Cetakan ketiga puluh. Jakarta: Balai Pustaka.

Setiawan, A. (2019). Sistem Kekerabatan Matrilineal dalam Adat Minangkabau pada Novel Siti Nurbaya: Kasih Tak Sampai Karya Marah Rusli. JURNAL ALFABETA. 2 (1) 92-104. DOI: https://doi.org/10.33503/alfabeta.v2i1.461

Supriatin, Y.M. (2010). Nasionalisme dalam Siti Nurbaya Karya Marah Rusli. JURNAL SOSIOTEKNOLOGI Edisi 19 Tahun 9, April 2010, 797-811.

Soerjono, Soekanto. (1990). Sosiologi Suatu Pengantar, Jakarta: Raja Grafindo Persada

Trisnawati. (2019). Analisis Nilai Sosial dalam Novel Sitti Nurbaya Karya Marah Rusli. Jurnal Artikula. 2/(2) 60-69. DOI: 10.30653/006.201922.31.

Yuhdi, A. (2020). Pandangan Dunia dalam Sajak Seorang Tua kepada Istrinya Karya W.S. Rendra. Jurnal Basastra. 9 (1), 83-94. DOI: https://doi.org/10.24114/ bss.v9i1.17776

Zukhaira, dkk. (2014). Penyusunan Bahan Ajar Pengayaan berdasarkan Kurikulum 2013 dan Pendidikan Karakter Bahasa Arab Madrasah Ibtidaiyah. Jurnal Rekayasa. 12 (1), 79-90. 